\title{
DSGE Model \\ Of A Small Open Economy: France
}

Nabil Ben Arfa, University of Nice Sophia-Antipolis, France

\begin{abstract}
In this paper we asses the effects and the transmission mechanisms of domestic and external shocks (we take a productivity shock associated to an imported energy shock) on the macroeconomic variables of a small open economy, using a dynamic stochastic general equilibrium model. We estimate a DSGE model in an open economy: France. In a first step, we begin by studying the cyclical features of the French economy, those of its main trading partners and the USA; this exercise enables us to make comparisons between France and its European neighbours. Once the facts are established, we will describe our model, its main features, then we solve it, make calibration and check the effects of exogenous shocks on the economic variables through the response impulse functions and the variance decomposition. Finally, we make comparison between the model's statistical moments of order two and those related to real facts in order to assess the validity of the model. It appears from our investigation, a significant correlation of the French cyclical characteristics with those of its neighbours. The France economy is also more vulnerable to technology shocks than to price of imported energy shocks.
\end{abstract}

Keyword: Productivity shocks, imported energy shocks, DSGE model, Small open economy, France

\section{INTRODUCTION}

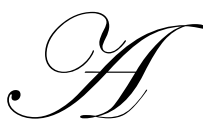

small open economy like France is vulnerable to various kinds of shocks from domestic as well as external origin; we quote: shocks on the prices of the imported energy, shocks on foreign exchange rates (or shocks on the terms of trade), shocks of productivity...

Empirical analyses on the effects of economic shocks on macroeconomic variables were often carried out using econometric methods especially structural VAR models. However, during the last years, there was an increasing grow of analysis based on simulation methods using dynamic stochastic general equilibrium models.

Indeed, parallel to the methodological renewal initiated by Sims (1980), VAR modelling, the Eighties were also marked by another theoretical and methodological revival. The first models emerging from this revival, real business cycles models caused a wide controversy.

Our days this controversy seems to be dissipated due to a principal reason, the methodological innovation to which this current of research gave birth: the principle according to which a macroeconomic model must be established by the aggregation of a series of microeconomic problems. This methodological innovation was adopted per many economists belonging to various economic schools of thought and various field of specialization. Works undertook using this methodology make possible the estimation of a large variety of shocks and economic structures.

DSGE Methodology (for Dynamic Stochastic General Equilibrium) generally starts with a complete specification of the model which equations are given according to a programme of intertemporal optimization of a representative agent with rational anticipation (or not). The model parameters are usually calibrated in order to compare the properties of the real data with those drawn from the theoretical model. The model is then simulated in order to assess the shocks effects on the economic activity. The well known DSGE model, considered also as the first model of this kind, is the Real Business cycle Model. 
In this paper, we asses the effects and the transmission mechanisms of domestic and external shocks (we take a productivity shock associated to a price imported energy shock) on macroeconomic variables of a small open economy, France, using a DSGE model.

Thus, we estimate a DSGE model in an open economy: France. At a starting point, we begin with the study of the cyclical features of the French economy, those of its main trading partners and the USA; this exercise enables us to make comparisons between France and its European neighbours. Once the facts established, we describe our model, its main features, then we solve it, make calibration and check the effects of the exogenous shocks on the economic variables through the response impulse functions and the variance decomposition.

Finally, we make comparison between the model statistical moments of order two and those related to the real facts in order to assess the validity of the model.

\section{CYCLICAL FEATURES OF THE FRENCH ECONOMY, THOSE OF ITS MAIN TRADING PARTNERS AND THE USA}

In this section we are interested in the economic business cycle as it was described and defined in the real business cycle theory. Thus, we analyse the join movement of five aggregates obtained from quarterly data: output, consumption, investment, worked hours, and trade balance reported to output.

These series enable us to describe the characteristics of the French economic fluctuations, those of the USA and those of its main trade partners, namely Germany, Spain and Italy. So we use the same method adopted in the real business cycles theory. Indeed, the series will be filtered according to Hodrick-Prescott method, the economic fluctuations features will be highlighted using the statistical moments of order two, a technique used by real business cycle authors to underline the stylized facts. Thus, variability, pro cyclicity and persistence of the cyclical components of variables are respectively measured by the standard deviation, the correlation with economic activity and the auto correlation.

\subsection{The French business cycle characteristics}

Table 1. Stylized facts of the French economy

\begin{tabular}{|l|c|c|c|c|}
\hline & Volatility & Relative volatility & Persistence & Correlation with GDP \\
\hline GDP & 0,80 & - & 0,86 & 1,00 \\
\hline Consumption & 0,77 & 0,96 & 0,67 & 0,82 \\
\hline Investment & 3,09 & 3,86 & 0,88 & 0,93 \\
\hline Net exports & 0,45 & 0,56 & 0,67 & $-0,25$ \\
\hline Total worked hours & 0,74 & 0,93 & 0,92 & 0,75 \\
\hline
\end{tabular}

Source: Ours estimation

All the variables, except for net exports, are transformed into logarithms then filtered.

Net exports are standardized by the GDP, and then filtered.

The studied period extends from the first quarter 1978 to the fourth quarter 2006 for all the variables except for net exports.

For net exports, the data extends from the first quarter 1990 to the fourth quarter 2006.

The French data are extracted from the quarterly database of the INSEE.

\subsection{The USA business cycle characteristics}

Table 2. Stylized facts of the USA

\begin{tabular}{|l|c|c|c|c|}
\hline & Volatility & Relative volatility & Persistence & Correlation with the GDP \\
\hline GDP & 1,33 & - & 0,81 & 1,00 \\
\hline Consumption & 1,03 & 0,77 & 0,84 & 0,81 \\
\hline Investment & 3,74 & 2,81 & 0,85 & 0,94 \\
\hline Net exports & 0,36 & 0,27 & 0,83 & $-0,36$ \\
\hline
\end{tabular}

Source: Ours estimation

The data are quarterly extending from the first quarter 1987 to the second quarter 2004.

The data are extracted from the OECD database. 


\subsection{The German Business cycle features}

Table 3. Stylized facts of the German economy

\begin{tabular}{|l|c|c|c|c|}
\hline & Volatility & Relative volatility & Persistence & Correlation with the GDP \\
\hline GDP & 0,84 & - & 0,68 & 1,00 \\
\hline Consumption & 0,96 & 1,14 & 0,32 & 0,62 \\
\hline Investment & 2,70 & 3,21 & 0,67 & 0,71 \\
\hline Net exports & 0,70 & 0,83 & 0,49 & $-0,44$ \\
\hline
\end{tabular}

Source: Ours estimation

The studied data are quarterly, extending from the first quarter 1991 until the second quarter 2004.

The data are extracted from the OECD database.

\subsection{The Spain Business cycle features}

Table 4. Stylized facts of the Spain economy

\begin{tabular}{|l|c|c|c|c|}
\hline & Volatility & Relative volatility & Persistence & Correlation with the GDP \\
\hline GDP & 0,75 & - & 0,72 & 1,00 \\
\hline Consumption & 1,03 & 1,37 & 0,70 & 0,78 \\
\hline Investment & 2,15 & 2,86 & 0,85 & 0,73 \\
\hline Net exports & 0,71 & 0,94 & 0,59 & $-0,38$ \\
\hline
\end{tabular}

Source: Ours estimation

The studied data are quarterly extending from the first quarter 1995 until the second quarter 2004.

The data are extracted from the OECD database.

\subsection{The Italy business cycle features}

Table 5. Stylized facts of the Italian economy

\begin{tabular}{|l|c|c|c|c|}
\hline & Volatility & Relative Volatility & Persistence & Correlation with the GDP \\
\hline GDP & 0,96 & - & 0,82 & 1,00 \\
\hline Consumption & 1,1 & 1,14 & 0,84 & 0,64 \\
\hline Investment & 3,00 & 3,125 & 0,82 & 0,73 \\
\hline Net exports & 0,92 & 0,95 & 0,74 & $-0,14$ \\
\hline
\end{tabular}

Source: Ours estimation

The data studied are quarterly extending from the first quarter 1981 until the second quarter 2004.

The data are extracted from the OECD database.

\subsection{Description of the results}

To comment these tables, we refer to some results highlighted by real business cycle theory. So the standard deviation of output is in general higher than that of consumption and lower than that of investment, a fact confirmed by our results. However, for the consumption which volatility is slightly lower than that of the GDP in France and in the USA (so in agreement with the real business cycle theory), for the remainder sample of countries, the result is in contrast with the theory predictions.

The pro cyclical characteristic of consumption, investment and hours worked (hours worked are only related to the French economy $)^{1}$ is well performed, the contra cyclical characteristic of the trade balance too. Indeed, the coefficient of correlation between real GDP, consumption, investment and hours worked is positive, which means that these variables are pro cyclical with the GDP. However, the coefficient of correlation between real GDP and trade balance is negative, thus trade balance is contra cyclical. Our results are conforming to those founded in the main studies dealing with economic fluctuations analysis, especially those of the RBC theory.

\footnotetext{
${ }^{1}$ We do not succeed to find hours worked data for the remainders countries.
} 
After having exposed countries stylized facts, particularly those of the France economy. It would be useful to consider what relation the French economy maintains with the remainder countries, so we will try to answer the following questions:

Are there a positive correlation between the French macroeconomic variables and those of the other countries? Are the French business cycle aligned on that of its main trader partners and on that of the USA?

Affirming that the French business cycle is synchronized with that of the remainder countries means that France (as its main trading partners) is probably hit by symmetric shocks.

\subsection{Individual correlation between France and the remainder countries}

Table 6. Cross country correlation

\begin{tabular}{|l|c|c|c|c|}
\hline & The United States & Germany & Spain & Italy \\
\hline Real GDP & 0.28 & 0.50 & 0.74 & 0.67 \\
\hline Consumption & 0.50 & 0.57 & 0.75 & 0,53 \\
\hline Investment & 0.53 & 0.33 & 0.34 & 0,49 \\
\hline Net export & 0,38 & -0.23 & -0.058 & 0,12 \\
\hline
\end{tabular}

Source: Ours estimation

The data are extracted from the quarterly database of OECD.

The results of the table above show that the principal aggregates of the French economy are correlated positively with those of the remainder countries and more particularly with those of its main trading partners belonging to the Economic and Monetary European Union (except for the trade balance).

Our results seem to confirm the business cycles synchronization of the European Monetary Union countries, and thus we can suppose that the States members are affected by symmetrical shocks ${ }^{2}$.

After having described the stylized facts of the French economy in comparison with its neighbour's countries and the USA, we also check the international cross country correlations. In what follows, we will asses the response of the model to the exogenous shocks defined in the beginning of this paper. This exercise will be applied to the French economy; of course we begin by the model specification, checking the steady state solution, and the parameters calibration.

\section{THE MODEL}

\subsection{Specification of the model}

Our economy consists on a large number of identical agents, acting as "price takers" in the various markets in which they take part.

\subsubsection{Preferences}

In the model there are an infinite number of identical households and the representative households maximize the expected value of future utility.

$$
U\left(C_{t}, N_{t}\right)=E_{0} \sum_{t=0}^{\infty} \beta^{t} \frac{1}{1-\sigma}\left[\left(C_{t}-\theta N_{t}^{v}\right)^{1-\sigma}-1\right] \quad \sigma>1 \text { and } v>1
$$

\footnotetext{
2 These results are conforming to the Optimum Currency Area theory.
} 
$E_{0}$, the mathematical expectation conditionally to information available at the date zero $(T)$.

$C_{t}$, represents the good consumption.

$N_{t}$, represents labours.

$v$, represents the intertemporal elasticity of substitution of labour supply.

$\beta$, the fixed factor of discount: it is a preference fixed parameter or preference factor through the time; it evaluates the impatience of individuals for consumption ${ }^{3}$.

$\theta$, this parameter measure the utility of consumption relative to the utility of leisure (the disutility of labour).

$\sigma$, the risk aversion parameter.

The utility function $U$ is supposed to be concave, continuous, differentiable, and satisfies the Inada conditions.

In this specification of utility function, the elasticity of substitution associated to leisure is equal to zero. This utility function was introduced for the first time by Greenwood, Hercowitz and Huffman $(1988)^{4}$, and is largely used in the RBC models in closed as in open economy (Correia et al. (1995), Crucini (1999) for example).

Correia and al. (1995) $)^{5}$ in their article "Business Cycles in Small Open Economy" compare the dynamic implications of this kind of utility function with the Cobb-Douglas utility function, both with a fixed factor of discount. They found that the Cobb-Douglas utility functions are less powerful than those introduced by GHH (Greenwood, Hercowitz and Huffman), particularly in concern with the volatility of consumption, the contracyclicity of net exports and their relationships to the stylised facts.

\subsubsection{Technology}

The model describes in this article is a standard dynamic stochastic general equilibrium model of a small open economy, France. The economy is supposed to be a small open economy which means that its behaviours do not influence the rest of the world; the country is considered as a "price taker".

Firms have access to the same techniques of production characterized by a CES production function. They are supposed to produce a single good, the domestic good.

The production function is defined as follows:

$Y_{t}=A_{t} N_{t}^{\alpha}\left[(1-\psi) k_{t}^{-v}+\psi e_{t}^{-v}\right]^{-(1-\alpha)}$

Where

\footnotetext{
${ }^{3}$ We can find discount factors described as endogenous; these parameters are often used to mitigate the problem of stationnarity encountered in DSGE models on open economy with imperfect market. For more details the interested reader can refer to the paper of Kim, S.H. and A. Kose, Dynamics of Open Economy Business Cycles Models: Understanding the Role of Discount Factor, Macroeconomic Dynamic, Vol. 7, No.2, pp.263-290, 2003.

${ }^{4}$ Greenwood, J., Z. Hercowitz and G. Huffman, Investment, Capacity Utilization and the Real Business Cycle, American Economic Review, Vol.78, No.3, pp.402-417, 1988.

${ }^{5}$ Correia, I., J. Neves and S. Rebello, Business Cycles in Small Open Economy, European Economic Review,Vol.39, No.6, pp.1089-1113, 1995.
} 
$Y_{t}$, is the production.

$K_{t}$, the stock of capital at the date $T$.

$N_{t}$, the quantity of work.

$e_{t}$, the imported energy.

$A_{t}$, an exogenous shock of productivity which we will be described there after.

$\alpha$, the share of labour in production.

$v$, represents the elasticity of substitution between capital and energy, this parameter is often higher than one in CES functions of production (constant elasticity of substitution).

The production has a constant elasticity of substitution between capital and imported energy, Cobb-Douglas between these two factors and worked hours.

The single good produced in this economy can be used for private consumption $\left(C_{t}\right)$, for public consumption $\left(G_{t}\right)$ and for investment $\left(I_{t}\right)$. The difference between total production $\left(Y_{t}\right)$ and absorption $\left(C_{t}, G_{t}, I_{t}\right)$ is the trade balance $\left(N X_{t}\right)$.

Thus the aggregate constraint equation is:

$Y_{t}=C_{t}+I_{t}+G_{t}+N X_{t}$

The public expenditure is supposed to be exogenous and is defined as follows:

$G_{t}=s g * Y_{t}$

$s g$ is a constant, it represents the average share of public expenditure in the production ${ }^{6}$.

In term of public expenditure, we follow Correia and al (1995) conclusions. In fact, they considerate that government expenditure and transfers do not generate a significant dynamic in small open economy model with GHH utility function, their effects on economic activity are insignificant. That's why we do not impose any budgetary nor foreign transfers' impulse to our variables ${ }^{7}$.

In the model, households accumulate capital which they rent to firms. At each period, the stock of capital depreciates in rate $\delta$ and increases with the investment $I_{t}$ :

$$
K_{t+1}=(1-\delta) K_{t}+I_{t}-\Phi\left(K_{t}, K_{t+1}\right)
$$

\footnotetext{
${ }^{6}$ We suppose that government taxes (or finances) the domestic production with a proportionally taxe, sg, there is no transfers in the model.

${ }^{7}$ Sunghm Henry Kim and M. Ayhan Kose in a very interesting article relating to the factor of discount, adopt the same assumption as ours. Indeed, they trust Correia and al (1995) results, and do not introduce any budgetary shock nor of transfers into their model.
} 
The capital of the future period ( $\left.K_{t+1}\right)$ is equal to the initial stock of capital $\left(K_{t}\right)$ less the depreciation $\left(\delta K_{t}\right)$ plus the current investment $\left(I_{t}\right)$ less the capital adjustment $(\Phi()$.$) .$

$\delta$, is the depreciation rate of capital.

$\Phi($.$) , is the cost of adjustment capital function, it verifies the following conditions: \Phi()>0,. \Phi^{\prime}()>$.0 and $\Phi "()<$.0 .

This adjustment function is supposed to take the following quadratic form:

$\Phi\left(K_{t}, K_{t+1}\right)=\frac{\phi}{2}\left(\frac{K_{t+1}-K_{t}}{K_{t}}\right)^{2}$

We often introduce an adjustment function of capital in dynamic models of small open economy to avoid an excessive volatility of investment in response to the differentials variations of domestic-foreigners interest rates.

\subsubsection{External balance}

Representative firms have to purchase energetic product at the international energy market, where the price $(p)$ is determined exogenously. Moreover, representative household have the opportunity to buy and sells bonds $\left(B_{t}\right.$ ) on a perfectly competitive capital market; the constant international real interest rate is given exogenously.

The equation of net exports is therefore:

$N X_{t}=P_{t} e_{t}+B_{t+1}-\left(1+R^{*}\right) B_{t}$

Where

$N X_{t}$ is the net exports

$R^{*}$ is the international real interest rate

$B_{t}$ represent bonds

$P_{t}$ is the imported energy price

Finally we suppose that:

$\lim _{t \rightarrow \infty} E_{o}\left(B_{t+1} \frac{1}{\left(1+R_{t}\right)}\right)=0$

It is the assumption of tranversality, the "no ponzi game" assumption. This assumption makes possible the unicity of the equilibrium. 


\subsubsection{Stochastic environment}

We suppose that there are two exogenous stochastic shocks to which the economy is confronted. These shocks follow an AR (1) process:

- $\quad$ The first shocks is a well known supply shocks: the Productivity shock

$\log A_{t}=\rho_{A} \log A_{t-1}+\varepsilon_{t}^{A}$

- $\quad$ External exogenous shock: the imported energy shocks. In fact, France is a small open economy which influence on international price of energy is limited.

$\log P_{t}=\gamma_{0}+\gamma_{1} \log P_{t-1}+\varepsilon_{t}^{p}$

Where

$\varepsilon_{t}^{A} \sim N\left(0, \sigma_{A}^{2}\right)$, and $\varepsilon_{t}^{p} \sim N\left(0, \sigma_{p}^{2}\right)$

Thus we have defined the model and the main characterises of the small open economy.

Because of the assumption of a perfect and complet market, and using the representative agent character of our models, we are able to centralize the problem of representative households and competitive firms to a social planer's problem.

The resulting dynamic optimization problem can be solved using a standard Lagrange approach.

The social planner's problem is the following:

$\operatorname{Max} U\left(C_{t}, N_{t}\right)=E_{0} \sum_{t=0}^{\infty} \beta^{t} \frac{1}{1-\sigma}\left[\left(C_{t}-\theta N_{t}^{v}\right)^{1-\sigma}-1\right]$

S.C

$Y_{t}=C_{t}+I_{t}+G_{t}+N X_{t}$

$Y_{t}=A_{t} N_{t}^{\alpha}\left[(1-\psi) k_{t}^{-v}+\psi e_{t}^{-v}\right]^{-(1-\alpha)}$

$$
K_{t+1}=(1-\delta) K_{t}+I_{t}-\Phi\left(K_{t}, K_{t+1}\right)
$$

We replace $N X_{t}, G_{t}$ and $K_{t+1}$ by their expressions, and we substitute (3) and (4) on (2), so equation (2) becomes:

$$
\begin{aligned}
& (1-s g) A_{t} N_{t}^{\alpha}\left[(1-\psi) k_{t}^{-v}+\psi e_{t}^{-v}\right]^{\frac{-(1-\alpha)}{v}}=C_{t}+\left(K_{t+1}-(1-\delta) K_{t}+\right. \\
& \left.\frac{\phi}{2}\left(\frac{K_{t+1}-K_{t}}{K_{t}}\right)^{2}\right)+P_{t} e_{t}+B_{t+1}-\left(1+R^{*}\right) B_{t}
\end{aligned}
$$

The first order conditions of Lagrange are drawn from the following equation: 


$$
\begin{aligned}
& \mathfrak{I}=\operatorname{Max} E_{0} \sum_{t=0}^{\infty} \beta^{t} \frac{1}{1-\sigma}\left[\left(C_{t}-\theta N_{t}^{v}\right)^{1-\sigma}-1\right]+\lambda_{t}\left[(1-s g) A_{t} N_{t}^{\alpha}\left[(1-\psi) k_{t}^{-v}+\psi e_{t}^{-v}\right]^{-(1-\alpha)}-\right. \\
& \left.C_{t}-\left(K_{t+1}-(1-\delta) K_{t}\right)-\frac{\phi}{2}\left(\frac{K_{t+1}-K_{t}}{K_{t}}\right)^{2}-P e_{t}-B_{t+1}+\left(1+R^{*}\right) B_{t}\right]
\end{aligned}
$$

And they are described by the following equations:

$$
\begin{aligned}
& \frac{\partial \mathfrak{I}}{\partial C_{t}}=0:\left(C_{t}-\theta N_{t}^{v}\right)^{-\sigma}=\lambda_{t} \\
& \frac{\partial \mathfrak{I}}{\partial N_{t}}=0: \theta v\left(C_{t}-\theta N_{t}^{v}\right)^{-\sigma} N_{t}^{v-1}=\lambda_{t}\left[\alpha(1-s g) N_{t}^{\alpha-1} A_{t}\left((1-\psi) K_{t}^{-v}+\psi e_{t}^{-v}\right)^{\frac{-(1-\alpha)}{v}}\right] \\
& \frac{\partial \mathfrak{I}}{\partial K_{t+1}}=0: \lambda_{t}\left[1+\phi\left(\frac{K_{t+1}-K_{t}}{K_{t}^{2}}\right)\right]=
\end{aligned}
$$

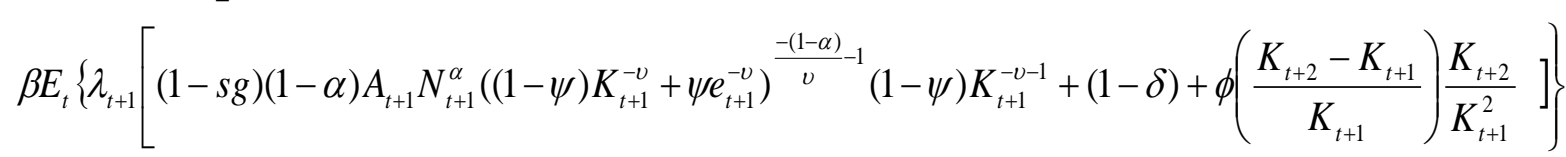

$$
\begin{aligned}
& \left.\frac{\partial \mathfrak{I}}{\partial e_{t}}=0: P_{t}=(1-s g)(1-\alpha) A_{t} N_{t}^{\alpha}\left[(1-\psi) K_{t}^{-v}+\psi e_{t}^{-v}\right]^{-(1-\alpha)}-1\right) \psi e_{t}^{-v-1} \\
& \frac{\partial \mathfrak{I}}{\partial B_{t+1}}=0: \lambda_{t}=\beta E_{t} \lambda_{t+1}\left(1+R^{*}\right) \\
& \frac{\partial \mathfrak{I}}{\partial \lambda_{t}}=0:(1-s g) A_{t} N_{t}^{\alpha}\left[(1-\psi) K_{t}^{-v}+\psi e_{t}^{-v}\right]^{-(1-\alpha)}= \\
& C_{t}+K_{t+1}-(1-\delta) K_{t}+\frac{\phi}{2}\left(\frac{K_{t+1}-K_{t}}{K_{t}}\right)^{2}+P_{t} e_{t}+B_{t+1}-\left(1+R^{*}\right)
\end{aligned}
$$

$\lambda$ is the multiplier of Lagrange associated to constraints

As we assume a small open economy model with perfect and competitive market, the neoclassical assumptions are verified; equilibrium and optimum are equivalent, and input factors are paid at their marginal products.

Domestic interest rate after depreciation is equal to:

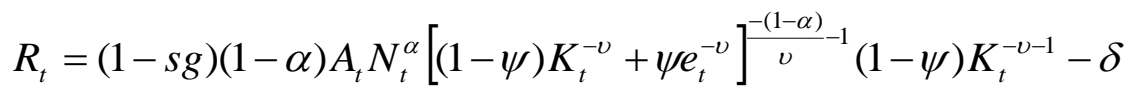


And real wage can be obtained as:

$$
w_{t}=\alpha(1-s g) A_{t} N_{t}^{\alpha-1}\left[(1-\psi) K_{t}^{-v}+\psi e_{t}^{-v}\right]^{-(1-\alpha)}
$$

Replacing $\lambda_{t}$ by its values (equation 6 ), we will have to solve the following final system of equations:

1) $\theta v N_{t}^{v-1}=\left[\alpha(1-s g) N_{t}^{\alpha-1} A_{t}\left((1-\psi) K_{t}^{-v}+\psi e_{t}^{-v}\right)^{\frac{-(1-\alpha)}{v}}\right]$

2)

$$
\begin{aligned}
& \left(C_{t}-\theta N_{t}^{v}\right)^{-\sigma}\left[1+\phi\left(\frac{K_{t+1}-K_{t}}{K_{t}^{2}}\right)\right]= \\
& \beta E_{t}\left\{\left(C_{t+1}-\theta N_{t+1}^{v}\right)^{-\sigma}\left[(1-s g)(1-\alpha) A_{t+1} N_{t+1}^{\alpha}\left((1-\psi) K_{t+1}^{-v}+\psi e_{t+1}^{-v}\right)^{\frac{-(1-\alpha)}{v}-1}(1-\psi) K_{t+1}^{-v-1}+(1-\delta)+\phi\left(\frac{K_{t+2}-K_{t+1}}{K_{t+1}}\right) \frac{K_{t+2}}{K_{t+1}^{2}}\right]\right\}
\end{aligned}
$$

3) $\left.P_{t}=(1-s g)(1-\alpha) A_{t} N_{t}^{\alpha}\left[(1-\psi) K_{t}^{-v}+\psi e_{t}^{-v}\right]^{-(1-\alpha)}-1\right) \psi e_{t}^{-v-1}$

4) $\left(C_{t}-\theta N_{t}^{v}\right)^{-\sigma}=\beta E_{t}\left[\left(C_{t+1}-\theta N_{t+1}^{v}\right)^{-\sigma}\left(1+R^{*}\right)\right]$

$$
\begin{aligned}
& (1-s g) A_{t} N_{t}^{\alpha}\left[(1-\psi) K_{t}^{-v}+\psi e_{t}^{-v}\right]^{-(1-\alpha)} v= \\
& C_{t}+K_{t+1}-(1-\delta) K_{t}+\frac{\phi}{2}\left(\frac{K_{t+1}-K_{t}}{K_{t}}\right)^{2}+P_{t} e_{t}+B_{t+1}-\left(1+R^{*}\right)
\end{aligned}
$$

6) $R_{t}=(1-s g)(1-\alpha) A_{t} N_{t}^{\alpha}\left[(1-\psi) K_{t}^{-v}+\psi e_{t}^{-v}\right]^{-(1-\alpha)}-10(1-\psi) K_{t}^{-v-1}-\delta$

7) $w_{t}=\alpha(1-s g) A_{t} N_{t}^{\alpha-1}\left[(1-\psi) K_{t}^{-v}+\psi e_{t}^{-v}\right]^{-(1-\alpha)} v$

The social planner problem's is impossible to solve analytically, thus we will adopt an approximation method of the solution around the steady state. This method consists in the linearization of the solution around its deterministic steady state.

\subsection{The model solution}

We have determine the first order conditions of the model, in the other hand we know that the model is impossible to solve analytically, so to find the equilibrium we have to linearize it. To solve the model we have to determine first the deterministic steady state (ie equilibrium without any impulsions). Once the steady state defined, we can loglinearize model's equations around the steady state.

The steady state:

The deterministic steady state is defined as the long term equilibrium which can be reached by the system in absence of any random shocks. 
At the steady state all the variables are constant $\left(Y_{t}=Y_{t+1}, K_{t}=K_{t+1} \ldots\right)$, technology is normalized to 1 ( $A_{t}=A_{t+1}=1$ ), we can also eliminate the anticipation operator $E_{t}$.

From equation (2) in static state, we determine the expression of $e$ (imported energy) at the steady state:

$e=\left(\frac{p \beta(1-\psi)}{[1-\beta(1-\delta)] \psi}\right)^{\frac{1}{-v-1}} K$

From equation (3) in static state, we can find the steady state expression of $N$ :

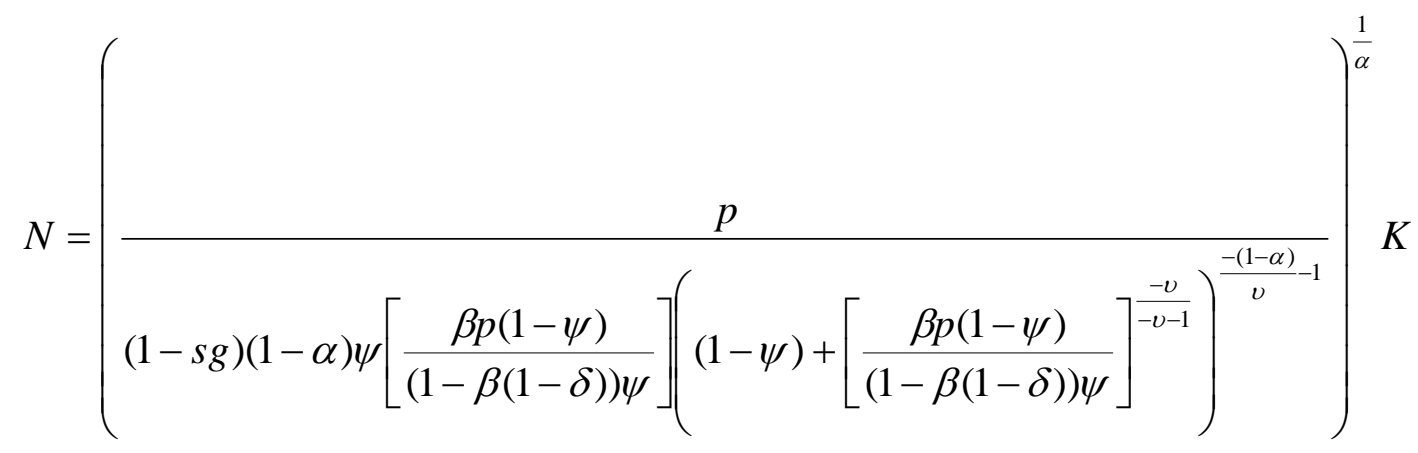

From equation (1) we have the expression of $(K)$

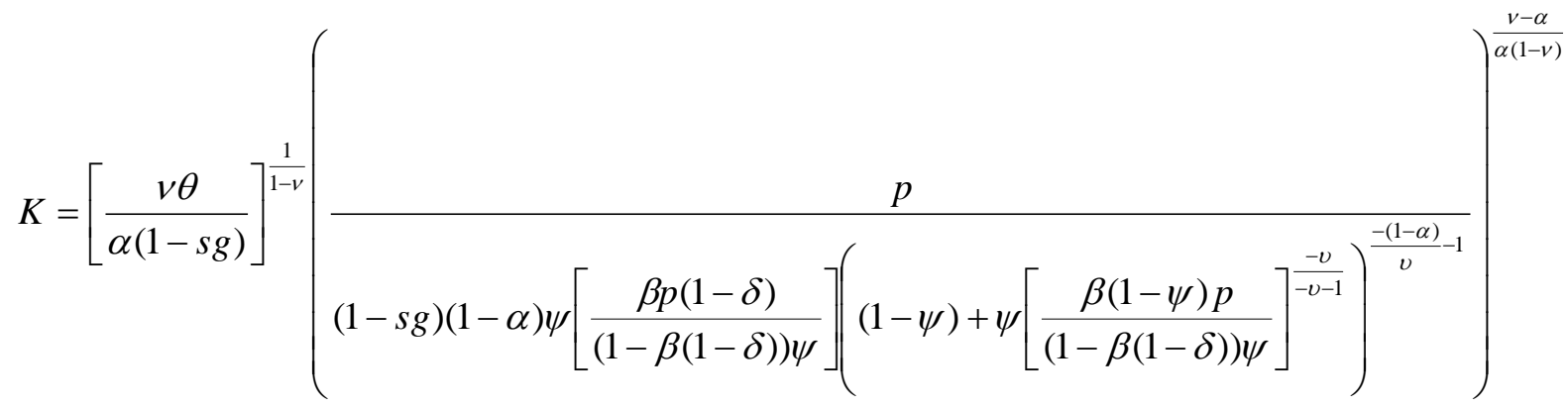

$$
\begin{aligned}
& \left((1-\psi)+\psi\left[\frac{\beta p(1-\psi)}{(1-\beta(1-\delta)) \psi}\right]^{\frac{-v}{-v-1}}\right)^{\frac{(1-\alpha)}{v(1-v)}}
\end{aligned}
$$

From equation (4), we get the expression of the discount factor:

$$
\beta=\frac{1}{1+R^{*}}
$$

From the capital accumulation equation we find the investment expression at the steady state:

$$
I=\delta K
$$

The consumption steady state is drawn from equation (5): 


$$
C=(1-s g) N^{\alpha}\left[(1-\psi) K^{-v}+\psi e^{-v}\right]^{-(1-\alpha)}-\delta K-p e+R^{*} B
$$

\subsection{Calibration of the model parameters:}

The parameters of the model are calibrated, partly according to earlier studies related to the French economy, and partly according to our estimations.

Calibration drawn from earlier studies:

\begin{tabular}{|c|c|c|c|}
\hline $\mathrm{N}$ & $\beta$ & $\alpha$ & $\delta$ \\
\hline 0.20 & 0.9929 & 0.68 & 0.0125 \\
\hline
\end{tabular}

Source: Hairault (1995)

The parameter $\alpha$ corresponds to the share of labour in the French output. Depreciation capital rate is equal to 0.0125 per quarter. From the chosen value of $\beta$ (0.9929), we obtain a real interest rate equal to 0.0071 .

The others parameters are calibrated basing in our estimation:

The trade balance average is calculated from our data, we reported it to GDP because of negative values.

$$
\frac{N X}{Y}=0.00057
$$

The $\psi$ parameter is drawn from the imported energy expression, $e$, at the steady state; for that we need to calibrate the ratio $\frac{e}{k}$ basing in data:

$$
\frac{e}{k}=0.0356
$$

$\theta$ is drawn from the expression of $n$ at the steady state, we obtain a value of 1.8246 .

The parameter $s g$ is obtained basing in our data by making the ratio between the expenditure average and the GDP average, its value is equal to 0.30 .

We retained a value of $N=0.20$ as an average of hours worked.

Calibration of stochastic process:

The parameters which characterise the properties of the stochastic process of the model are determined by the estimation of an autoregressive process of order one (AR (1)) of the imported energy price and the Solow residual.

The calculation of the Solow residual is carried out in the following way: 
The Solow residual, also called total factor productivity (TFP) is obtained by dividing the Gross Domestic Product by the factors of production contribution (Capital, imported energy and labour).

$T F P=\frac{Y}{F(K, N, E)}$

Where $F(K, N, E)=N_{t}^{\alpha}\left[(1-\psi) k_{t}^{-v}+\psi e_{t}^{-v}\right]^{-\frac{(1-\alpha)}{v}}$

Calculated TFP is then taken in logarithm and filtered according to Hodrick-Prescott method, finally we estimate an autoregressive model of this form:

$\log A_{t}=\rho_{A} \log A_{t-1}+\varepsilon_{t}^{A}$

Imported energy price shock is estimated according to the following equation:

$\log P_{t}=\gamma_{0}+\gamma_{1} \log P_{t-1}+\varepsilon_{t}^{p}$

In deed, the energy price is transformed to logarithm, and then filtered and finally regressed in an AR (1) model.

To summarize, we expose in the table above the various parameters of the model:

Table 7. Parameters of the model

\begin{tabular}{|l|l|}
\hline \multicolumn{2}{|l|}{ Period: $1978-2004$} \\
\hline Parameters \\
\hline Production & 0.68 \\
\hline$\alpha$ & 0.80 \\
\hline$U$ & 0.0002 \\
\hline$\psi$ & 0.993 \\
\hline Preferences & 1.001 \\
\hline$\beta$ & 1.7 \\
\hline$\sigma$ & 1.8707 \\
\hline$\nu$ & \\
\hline$\theta$ & 0.0125 \\
\hline The accumulation of capital & 30 \\
\hline$\delta$ & \multicolumn{2}{|l|}{} \\
\hline$\phi$ & 0.5289 \\
\hline Exogenous shocks & 0.000370 \\
\hline$\rho_{A}$ & 0.71405 \\
\hline$\gamma_{0}$ & 0.0071 \\
\hline$\gamma_{1}$ & \\
\hline$R^{*}$ & \\
\hline
\end{tabular}

Sources: Our own estimates and those drawn from earlier studies. 


\subsection{The simulation Results}

To solve the model and to make ours stochastic simulations, we use the mathematical Software Matlab ${ }^{8}$ and the programme Dynare - a pre processor and a collection of Matlab routines (Juillard 2003)-. These routines enable us to linearize the model equations around the steady state equilibrium; thereafter we could simulate the model and determine the effects of exogenous shocks on the main economic variables of the economy.

\subsubsection{Impulses response functions of the shocks}

In this part, we analyze the effects of the two shocks on the economic variables of the model. We use the same specification and the same parameters of the theoretical model in order to asses the effect of a $1 \%$ stochastic impulse on the macro-economic aggregates variables, and to analyze the response of these economic variables to these impulses.

\subsubsection{The impulses responses functions of imported energy price}
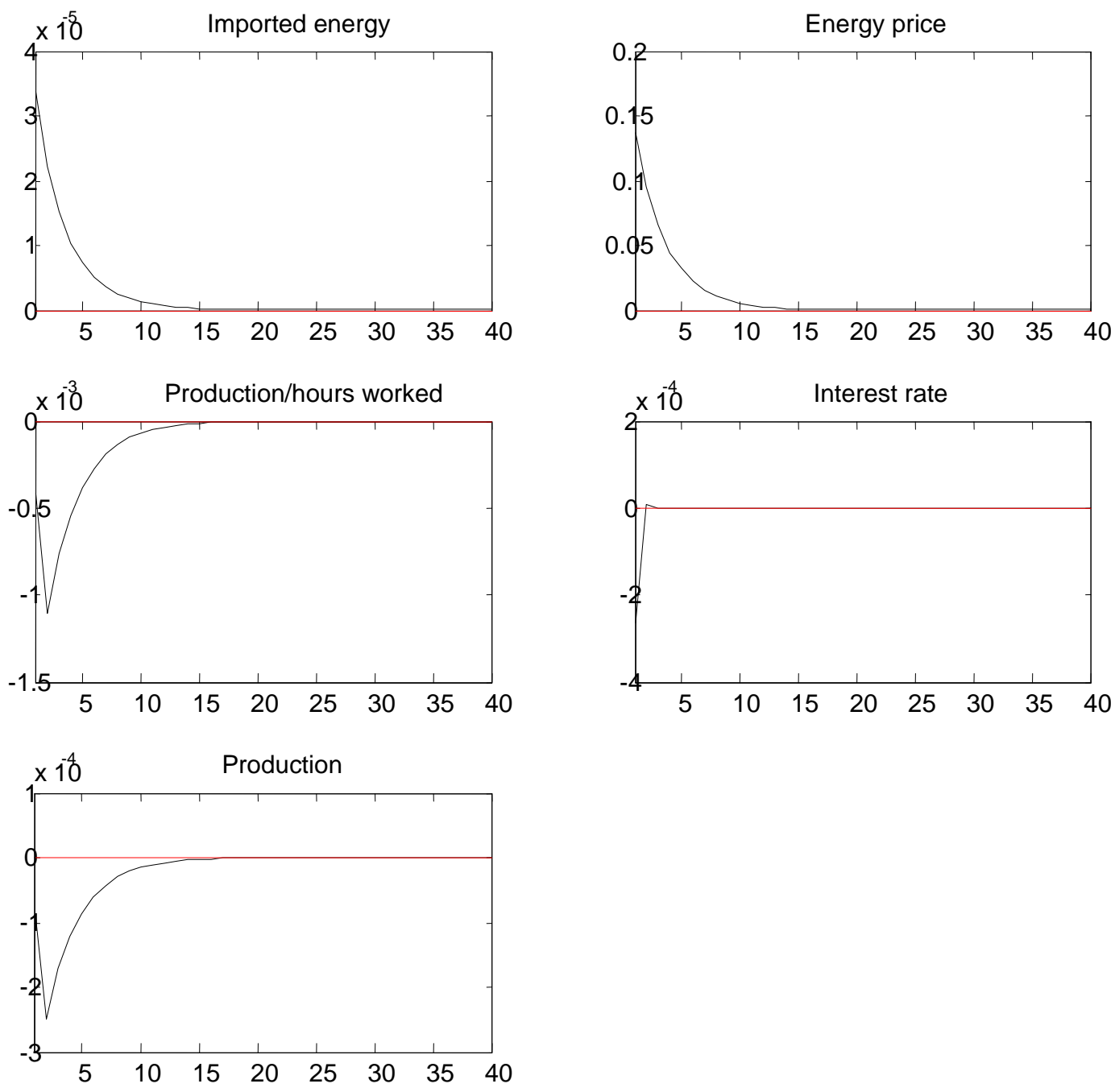

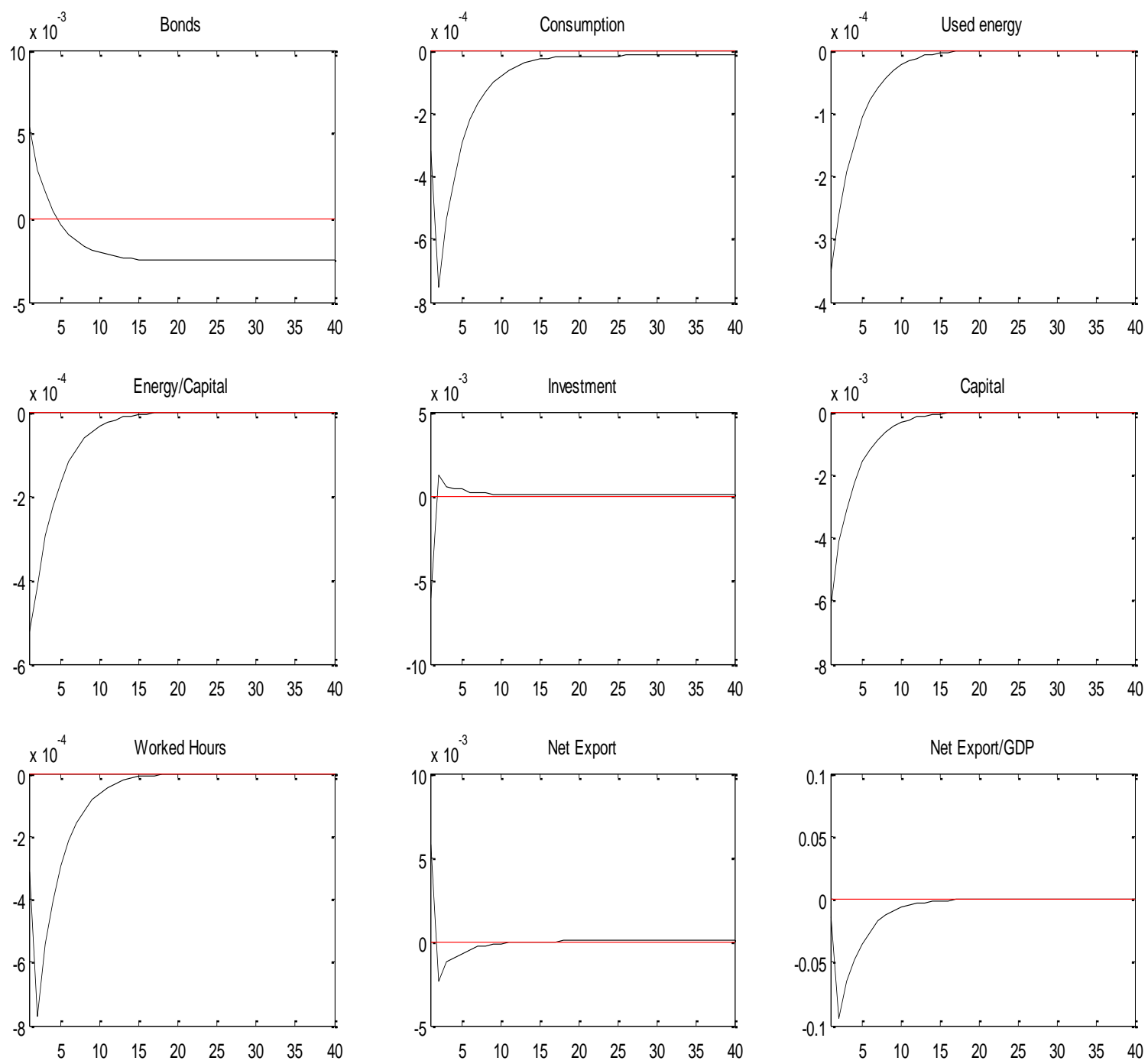

The occurrence of an energy price shock leads to a reduction of the energy uses as a production factor. This fall of energy utilization determines the answer of the capital factor, considering the complementarities of the two factors in the production function; thus the capital decrease and hours worked too.

The raise of energy price leads to an increase of energy imports values which generates the fall of the production, consumption and the investment as shown in the figure $n^{\circ} 1$ above.

Another effect of energy utilization fall, concerns the decrease of the marginal productivity of the domestic capital, which generates an increase in the foreign titles purchase. This effect combined with that of the increase in the value of the imported energy generates a deterioration of the external balance position of the country.

To summarize, an energy price shocks, conduct the French economy to a recession, which consolidate the economic theory predictions on the harmful effects of energy shocks. 


\subsubsection{Impulse response functions of the technological shock}

Figure 2: Impulse response functions of productivity impulses
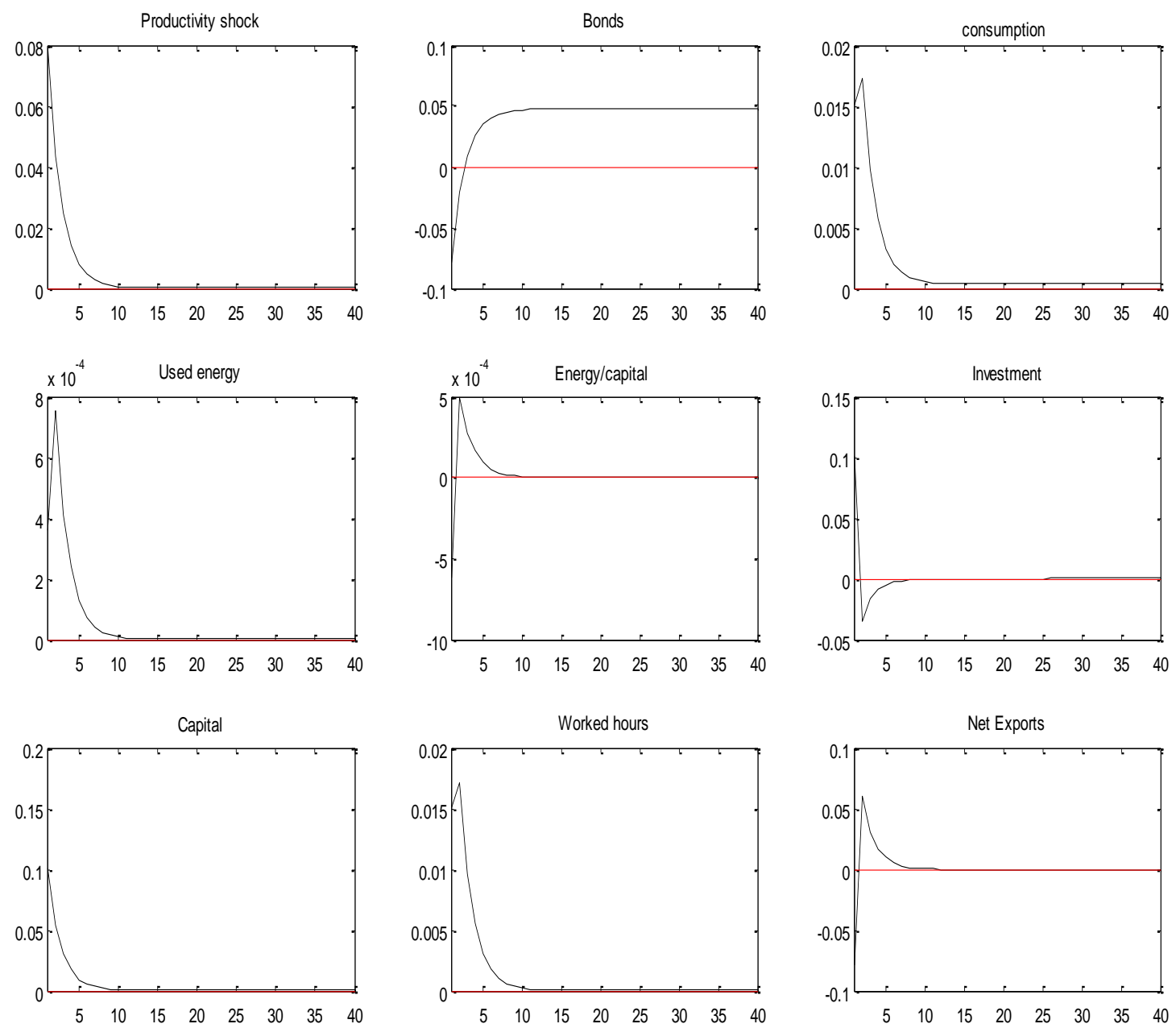

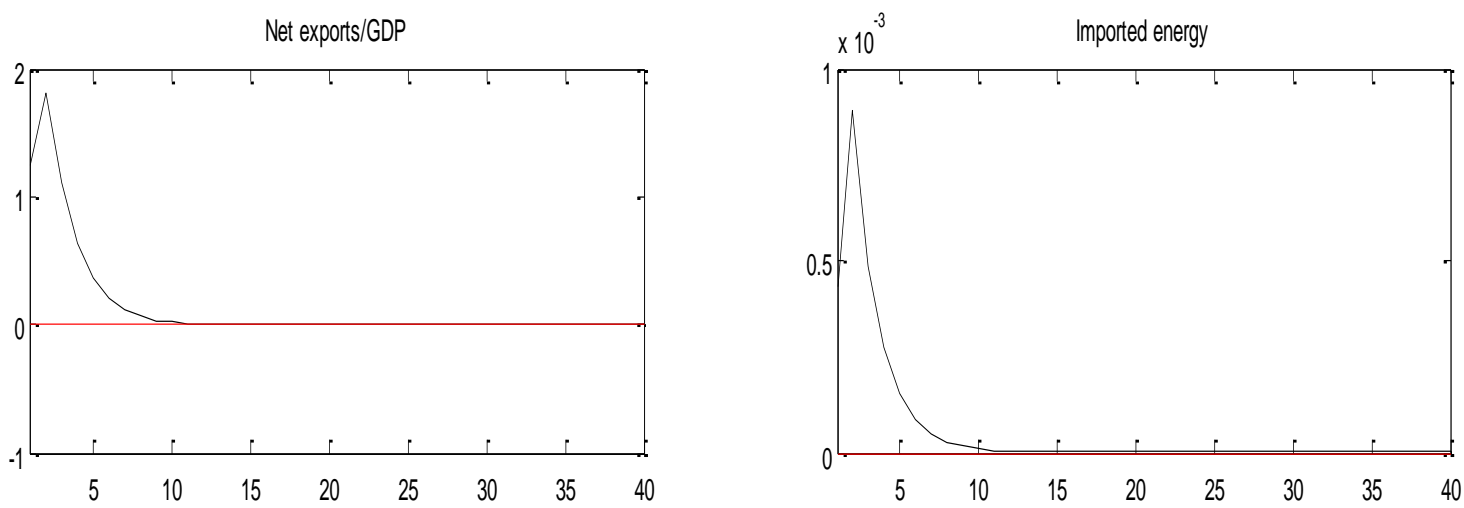

Production/Worked hours

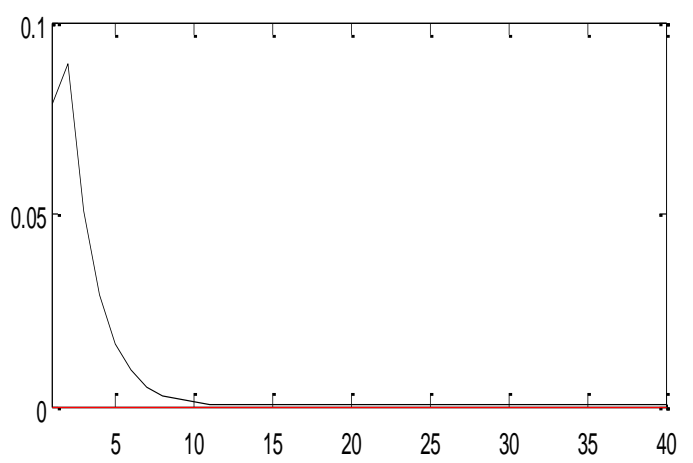

International interest rate
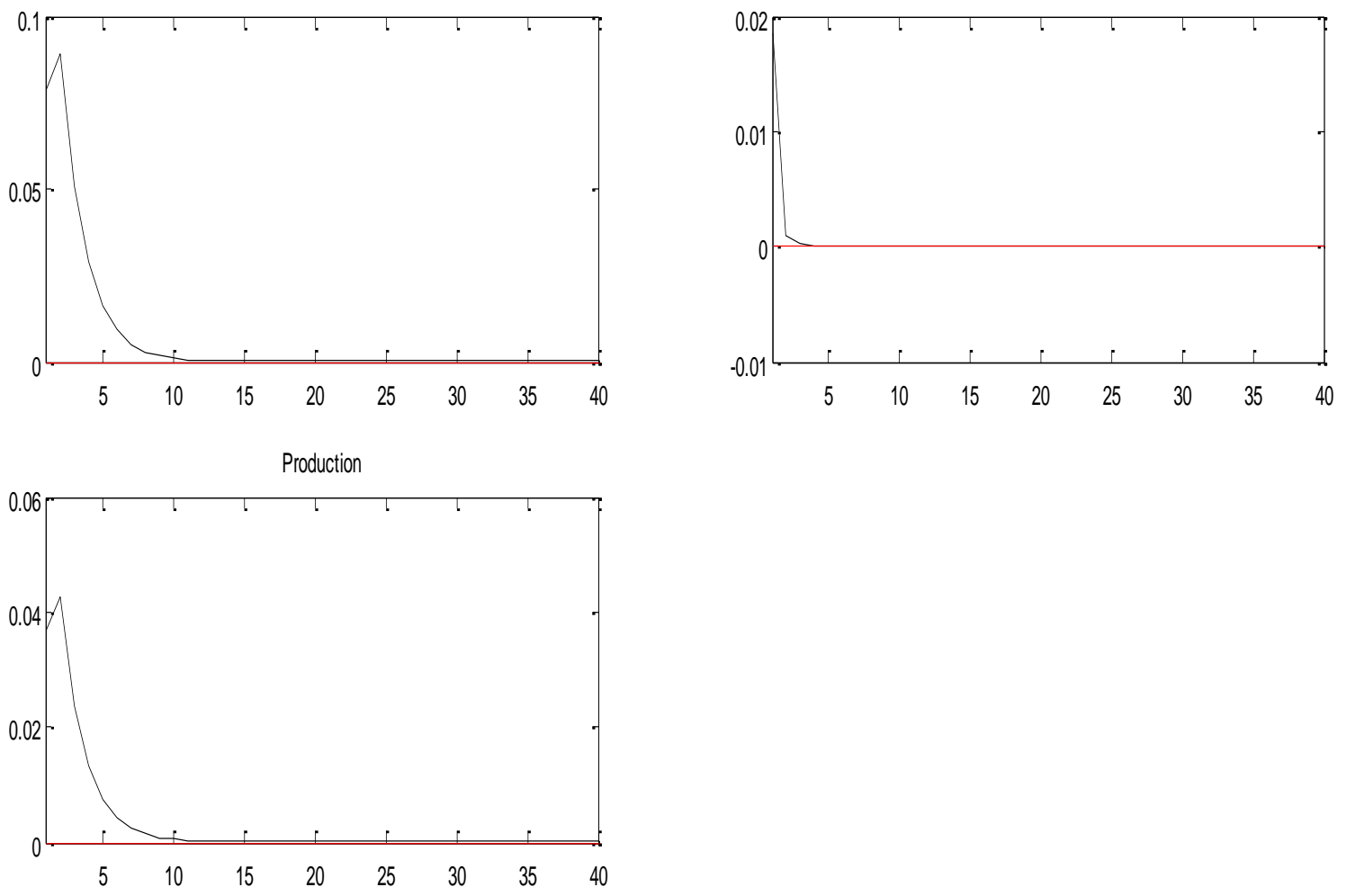

The effect of a productivity shock is the same as it was described in the RBC models. In deed, a temporary increase in the TFP causes a health effect which generates an increase in consumption and present leisure, moreover and through the smooth mechanism of consumption; this wealth effect affects in a same way the future consumption and leisure.

In other hand, the raise of TFP increases the wage rate and causes a substitution effect which generates a decrease in leisure. The global effect on labour (leisure) is positive (negative) in short term. The increase in the future consumption causes an increase in saving and investment too. 
The increase of production generates an increase in public expenditure, which increases even more production and factors productivity and thus stimulates the propagation mechanism described before. Now the increase in TFP will cause a substitution effect between the foreign assets and the domestic capital which generates a trade balance deficit (a fall of foreigner bonds sells). The domestic capital increase drops its income which encourages residents to replace it by foreign assets. So, the domestic capital will return to its steady state value.

To summarize, when a productivity shock occurs, the domestic activity increases via an increase in labour supply. This increase in the production, is partly consumed, and partly invested. Thus, as one could note it from the diagram, hours worked, consumption and investment react pro cyclically to a technological shock. The imported energy, as a complementary factor of production, will increase following the production evolution.

\subsubsection{The comparison between simulated moments of order two and those extracted from data}

Table 8. Cyclical properties of the theoretical model (simulation results)

\begin{tabular}{|l|c|c|c|c|c|c|}
\hline \multicolumn{1}{|c|}{ Variable } & $\begin{array}{c}\text { Production: } \\
\text { Y }\end{array}$ & $\begin{array}{c}\text { Consumption: } \\
\text { C }\end{array}$ & $\begin{array}{c}\text { Investment: } \\
\text { I }\end{array}$ & $\begin{array}{c}\text { Labour: } \\
\text { NR }\end{array}$ & $\begin{array}{c}\text { Imported } \\
\text { energy: E }\end{array}$ & $\begin{array}{c}\text { Net Export: } \\
\text { Nx }\end{array}$ \\
\hline Volatility & 0.76 & 0.22 & 1.09 & 0.36 & 0.01 & 1.05 \\
\hline $\begin{array}{l}\text { Volatility relating } \\
\text { to GDP }\end{array}$ & - & 0.29 & 1.43 & 0.47 & 0.013 & 1.38 \\
\hline Auto correlation & 0.6540 & 0.6527 & -0.2325 & 0.6540 & 0.6076 & 0.6629 \\
\hline $\begin{array}{l}\text { Correlation with } \\
\text { GDP }\end{array}$ & 1.000 & 1.000 & 0.9146 & 0.0322 & 0.5755 & 0.6391 \\
\hline
\end{tabular}

Source: ours estimation

Table 9. Stylised facts of the model (extracted from the data)

\begin{tabular}{|l|c|c|c|c|}
\hline & Volatility & Relative volatility & Persistence & Correlation with GDP \\
\hline GDP & 0,80 & - & 0,86 & 1,00 \\
\hline Consumption & 0,77 & 0,96 & 0,67 & 0,82 \\
\hline Investment & 3,09 & 3,86 & 0,88 & 0,93 \\
\hline Net exports & 0,45 & 0,56 & 0,67 & $-0,25$ \\
\hline Total hours worked & 0,74 & 0,93 & 0,92 & 0,75 \\
\hline
\end{tabular}

Source: Ours estimations

The comparisons between statistical moments resulting from the quarterly data and those drawn from the theoretical model can be carried out following the simulation of the model. The above two tables expose the principal results.

We note that the variability of the various aggregates is relatively well performed by the simulated model. However, this variability is slightly lower than that resulting from the data especially for consumption, investment and hours worked.

The classification of the relative variances of consumption, of investment and of output is well reproduced. We know that, in the facts and in real business cycle models, the production is more volatile than consumption, consumption is often less volatile than investment. This classification is well performed by our simulations. However the relative variability values of these aggregates variables are lower than those resulting from the data. Concerning the last characteristic on which RBC models are based, i.e. the persistence measured by the auto correlation of order one. We note that, in general, the persistent character of the model is well reproduced except for investment.

Finally, and concerning the correlation of aggregates variables with GDP. We can sustain that the pro cyclical character of investment and consumption is well performed. However, the simulated model is unable to reproduce the contra cyclical characteristic of the trade balance, even when it is considered as a robust stylised fact. This contrast with the stylised facts could be attributed to the competitive market assumption adopted in the model; this result can probably be improved if we extend our analysis to an economy operating in an imperfect market. 


\subsubsection{Variance error decomposition}

Table 10. Relative contribution of the two shocks to the variables variability

\begin{tabular}{|l|c|c|}
\hline \multicolumn{1}{|c|}{ Variable/Shock } & Energy shock & Productivity shock \\
\hline Foreign titles & 0.38 & 99.62 \\
\hline Consumption & 0.14 & 99.86 \\
\hline Imported energy & 66.89 & 33.11 \\
\hline Imported energy/Capital & 80.25 & 99.75 \\
\hline The public expenditure & 0.14 & 99.86 \\
\hline Investment & 0.28 & 99.86 \\
\hline Capital & 0.38 & 99.86 \\
\hline Hours worked & 0.14 & 99.68 \\
\hline Net exports & 0.32 & 99.86 \\
\hline Net Exports /PIB & 0.14 & 86.00 \\
\hline Production & 14.00 & 99.82 \\
\hline Interest rate & 0.18 & \\
\hline
\end{tabular}

Source: Ours estimations

Through the table above, we can determine the relative contribution of the two shocks (energy shock and technological shock) to the economic fluctuations of the French economy. We note that the effect of the technological shock is more important than that of the energy shock. Indeed, the technological shock contributes to $86 \%$ of the French economic fluctuation whereas the energy shock contributes to only $14 \%$.

The French economy is thus more vulnerable to supply shocks especially to TFP shocks.

\section{CONCLUSION}

In this article, we seek to describe the French business cycle characteristics over the period 1978-2006 using a stochastic dynamic equilibrium model.

Indeed, in a DSGE model of a small open economy describing the French economy, we exposed the stylized facts characterizing the French business cycle, and then we compared these facts, precisely the moments of order two, to those resulting from the theoretical model.

The results are relatively satisfactory concerning the reproduction of the stylized facts even if they are far from being perfect; in particular in concern with the trade balance, so in order to improve these results new assumptions should be introduced into the model. We can for example include assumptions on the international capital market.

The project of this paper consisted also in studying the effect of two shocks- energy shock and technological shock- on the French economy activity. The evaluation of the responses impulses functions of and the variance decomposition reveals a more important vulnerability of the French economy to technological shocks than to imported energy prices.

This result deserves more deepness in future work. We could extend this models in various directions, by introducing new theoretical assumptions (several goods, several sectors, imperfect market), by integrating new shocks...

These new assumptions would enable us to deduce more reliable conclusions.

\section{REFERENCES}

1. Ambler, S., E. Cardia and C. Zimmermann, International Business Cycles: What are the Facts? , Journal of Monetary Economics, Vol.51, No.2, pp. 257-276, 2004. 
2. Ambler, S., E. Cardia and C. Zimmermann, International Transmission of the Business Cycle in a MultiSector Model, European Economic Review, Vol.43, pp.273-300, 2002.

3. Backus, D. and P. Kehoe, International Evidence of the Historical Properties of Business Cycles, American Economic Review, Vol. 82, pp.864-888, 1992.

4. Backus, D., P. Kehoe and F. Kydland, International Real Business Cycles, Journal of Political Economy, Vol.100, No. 4, pp.745-775, 1992.

5. Backus, D., P. Kehoe and F. Kydland, Dynamics off the Trade Balances and the Terms Trade off: The JCurve? , American Economic Review, Vol. 84, pp.84-103, 1994.

6. Baxter, M. and R.G. King, Fiscal Policy in General Equilibrium, American Economic Review, Vol.83, No.3, pp.315-334, 1992.

7. Baxter, M. and M. Crucini, Explaining Saving-Investment Correlations”, American Economic Review, Vol.83, pp.416-436, 1993.

8. Bruneau, C. and F. Portier, A Small Open Economy Real Business Cycles Model: the French Economy Case, in Pierre-Yves Henin, ED., Advances in Business Cycles Research, Springer-Verlag, pp.173-194, 1995.

9. Campbell, J., Inspecting the Mechanism: An Analytical Approach to the Stochastic Growth Model, Journal of Monetary Economics, Vol.33, No. 3, pp.463-506, 1994.

10. Cantor, R. and N.C. Mark N.C., The International Transmission of Real Business Cycles, International Economic Review, Vol. 29, No.3, pp.493-507, 1988.

11. Cardia, E., The Dynamics of a Small Open Economy in Response to Monetary, Fiscal and Productivity Shocks", Journal of Monetary Economics, Vol.28, No.3, pp.411-434, 1991.

12. Christiano, L. and M. Eichenbaum, Current Real Business Cycles Theories and Aggregate Labor-Market Fluctuations, American Economic Review, Vol.82, No.3, pp.430-450, 1992.

13. Collard, F. and P., Modèles VAR ou DSGE : que choisir ? ", Workshop Economie et Prévision, Paris 14/09-15/09/2006, CEPREMAP.

14. Correia, I., J.C. Neves and S. Rebelo, Business Cycles in Small Open Economy, European Economic Review, Vol.39, No. 6, pp.1089-1113, 1995.

15. Costello, D. and J. Praschnik, The Role of Oil Price Shocks in a Two-Sector, Two Country Model of the Business Cycles, Department of Economics Working Paper, No.9208, University of Western Ontario, 1992.

16. Danthine, J.P. and J.B. Donaldson J.B., Methodological and Empirical Issues in Real Business Cycles Theory, European Economic Review, Vol. 37, No.1, pp.1-35, 1993.

17. Feldstein, M. and C. Horioka, Domestic Savings and International capital Flows, Economic Journal, Vol.90, pp.314-329, 1980.

18. Finn, M., One Savings and Investment Dynamics in a Small Open Economy”, Journal of International Economics, Vol.29, No.1, pp.1-22, 1990.

19. Gatti, D.D. and M. Gallegati, One the Nature and Cause of Business Fluctuations in Italy, 1861-2000, Explorations in Economic History, No.42, pp.81-100, 2004.

20. Giménez, E.L. and J.M. Moreno, One the Role of Money in a Business Cycles Model of a Small Open Economy: the case of Spain, Spanish Economic Review, Vol.4, No.3, pp.159-177, 2002.

21. Goodfreind, M., R.G. King, The New Classical Synthesis and the Role of Monetary Policy, NBER Macroeconomics annual, Cambridge, MIT Press.

22. Greenwood, J., Z. Hercowitz and G.W. Huffman, Investment, Capacity Utilization, and the Real Business Cycle, American Economic Review, Vol.78, No.3, pp.402-417, 1988.

23. Hairault, J.O and F. Portier, Nominal Rigidities and Monopolistic Competition: a New Keynesian View”, in Hénin, Advances in Business Cycles Research, 1995.

24. Hansen, G., Indivisible Labor and the Business Cycles, Journal of Monetary Economics, Vol.16, No.3, pp.309-327, 1985.

25. Hansen, G. and C. Prescott, Recursive Methods for Computing Equilibria of Business Cycles Models, in Cooley T.F. (ED), Frontiers off Business Cycles Research. Princeton, Princeton University Press, 1995.

26. Harjes, T., Real Business Cycles in an Open Economy: an application to Germany, Weltwirtschaftliches Archive, Vol.133, pp.635-656, 1997.

27. Henin, P.Y., Une macroéconomie sans monnaie pour les années 90, Revue d'Economie Politique, Vol.99, No. 4, pp.531-596, 1989. 
28. Hunt, B.R., R.L. Lipsman and J.M. Rosenberg, A Guide to MATLAB: for Beginners and Experienced Users, Cambridge, New York, 2001.

29. Julliard, M., DYNARE: a program for Solving Rational Expectation Models, Edition 2.6.1.1 for Dynare Version 2.6.1, CEPRAMAP, 2003.

30. Kehoe, P.J. and F. Perri, International Business Cycles with Endogenous Incomplete Markets, Econometrica, Vol.70, No.3, pp.907-928, 2002.

31. Kim, S.H. and A. Kose, Dynamics of Open Economy Business Cycles Models: Understanding the Role of the Discount Factor, Macroeconomic Dynamic, Vol.7, No. 2, pp.263-290, 2003.

32. King, R.G., Ch. Plosser and S. Rebelo, Production, Growth and Business Cycles: I. the Basic Neoclassical Model, Journal of Monetary Economics, Vol.21, No.2, pp.195-232, 1988a.

33. King, R.G., Ch.Plosser and S. Rebelo S., Production, Growth and Business Cycles: .II New Directions, Journal of Monetary Economics, Vol. 21, No. 2, pp.309-341, 1988b.

34. King, R.G., Ch. Plosser and S. Rebelo, Production, Growth and Business Cycles: Technical Appendix, Computational Economics, Vol.20, pp.87-116, 1988.

35. King, R.G., Ch. Plosser and S. Rebelo, Resuscitating Real Business Cycles, in John Taylor and Michael Woodford, eds, Handbook of Macroeconomics, Vol.1, Chapter 14, pp.928-1002, 1999.

36. Knight, A, Basics of MATLAB and Beyond, CHAPMAN and HALL/CRC, 1999.

37. Kose, Ayhan M., Explaining Business Cycles in Small Open Economies: How Much do World Prices Matter?, Journal of International Economics, Vol.56, No. 2, pp. 299-327, 2002.

38. Kydland, F.E. and E.C. Prescott, Time to Build and Aggregate Fluctuations, Econometrica, Vol.50, No.6, pp.1345-1370, 1982.

39. Kydland, F.E. and E.C. Prescott, The Econometrics of the General Equilibrium Approach to Business Cycles, Scandinavian Journal of Economics, Vol. 93, No.2, pp.161-178, 1991.

40. Kydland, F.E. and E. C. Prescott, The Computational Experiment: an Econometric Tool, Journal of Economic Perspectives, Vol. 10, No. 1, pp.69-85, 1996.

41. Long, J.B. and C. Plosser, Real Business Cycles, Journal of Political Economy, Vol.91, No. 1, pp.39-69, 1983.

42. Mankiw, G., Real Business Cycles: a New Keynesian Perspective, Journal of Economic Perspectives, Vol. 3, No. 3, pp.79-90, 1989.

43. Mendoza, E.G., Real Business Cycles in a Small Open Economy, American Economic Review, Vol.81, No. 4, pp.797-818, 1991.

44. Plosser, C., Understanding Real Business Cycles, Journal of Economic Perspectives, Vol.3, No. 3, pp.5157, 1989.

45. Prescott, E., Theory Ahead Business Cycles Measurement, Federal Reserve Bank of Minneapolis Quarterly Review, pp.9-22, 1986.

46. Rebelo, S., Real Business Cycles Models: Past, Present, and Future, NBER Working Paper, No. 11401, 2005.

47. Sargent, T. and L. Ljungqvist, Recursive Macroeconomic Theory, Cambridge, MIT Press, 2004.

48. Schmitt-Grohé, S. and M. Uribe, Solving Dynamic General Equilibrium Models Using a Second Order Approximation to the Policy Function, Journal of Economic Dynamics and Control, Vol.28, No. 4, pp.755775, 2004.

49. Schmitt-Grohé, S. and M. Uribe, Closing Open Economy Models, Journal of International Economics, Vol.61, No. 1, pp.163-185, 2001.

50. $\quad$ Stadler, G.W., Real Business Cycles, Journal of Economic Literature, Vol. XXXII, pp.1750-1783, 1994.

51. Stockman, A. and L. Tesar, Tastes and Technology in a Two-Country Model of the Business Cycles: Explaining International Comovements, American Economic Review, Vol.85, No. 1, pp.168-185, 1995.

52. Uhlig, H., A Toolkit for Analyzing Nonlinear Dynamic Stochastic Models Easily, Federal Reserve Bank of Mineapolis, Institute for Empirical Macroeconomics, Discussion Paper, No.101.

53. Zimmermann, C., International Real Business Cycles among Heterogeneous Countries, European Economic Review, Vol.41, No. 2, pp.319-355, 1997. 
NOTES 